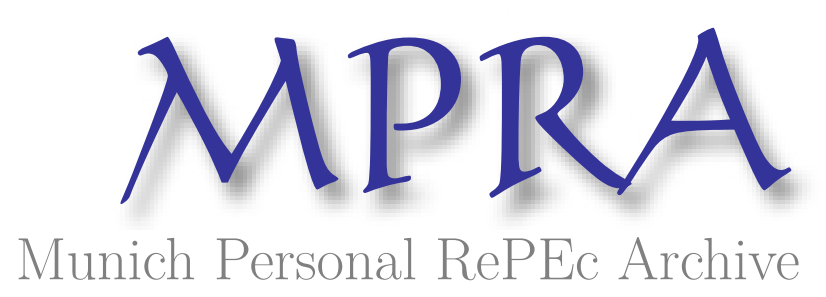

\title{
Applied economic model for an innovation growth
}

Josheski, Dushko and Magdinceva-Sopova, Marija

"Goce Delcev" University, Stip

November 2013

Online at https://mpra.ub.uni-muenchen.de/51290/

MPRA Paper No. 51290, posted 08 Nov 2013 14:51 UTC 


\title{
Applied economic model for an innovation growth
}

\author{
Dushko Josheski* and Marija Magdinceva-Sopova \\ "Goce Delcev" University, Stip, R. Macedonia
}

\begin{abstract}
The issue of institutional support for innovations in Latin American countries has been examined in this paper. We use aprirori theoretical knowledge on this issue in order to derive one econometric model out of a theoretical framework. The influence on human capital variable on innovations growth it is straightforward. However, the sign on the institutions variable is ambiguous. Defective institutions in Latin American countries resulted in regional's social conflicts which were severe, and the ability of social groups to use formal political institutions to resolve, or mitigate this conflicts has been much less effective. The lack of democracy if we may say, deteriorates the entrepreneurial spirit and hence institutions may as well turn not to be supportive of innovations.
\end{abstract}

Key words: Innovations, human capital, quality of institutions, Latin America

\footnotetext{
* Corresponding author. E-mail: dushkojosheski@gmail.com.
} 


\section{Introduction}

In this paper the issue of institutions support for innovations has been investigated on the panel of Latin American countries. In the macroeconomic literature there has been consensus made, that the long run growth is product primary of innovations. The economists are still trying to set up a standard theoretical framework for long run economic growth that will incorporate institutions and innovations, Sala-i-Martin, (2002) $)^{1}$; Huang and $\mathrm{Xu},(1999)^{2}$. The fundamental importance of institutions for economic growth through their influence on innovations was long ago being recognized by the economist Joseph Schumpeter. New growth economists namely Romer, 1990³ Grossman and Helpman.19914; and Aghion and Howit, $1992^{5}$; had made breakthroughs in endogenizing technological change. However, in this models institutions are taken as given, and there is little or no

\footnotetext{
${ }^{1}$ Sala-i-Martin, Xavier X. (2002). "15 Years of New Growth Economics: What Have We Learnt?" Central Bank of Chile, Working Paper 172, 22p.

2 Huang, Haizhou and Chenggang Xu (1999). "Institutions, Innovations and Growth," American Economic Review, 89(2): 438-443.

3 Romer, Paul,(1990) ,"Endogenous Technological Change." Journal of Political Economy, October 1990, 98(5), pp. '71-102.

4 Grossman, Gene and Helpman, Elhanan(1991). "Quality Ladders in the Theory of Growth." Re-view of Economic Studies, January 1991, 58(1), pp. 43-61.

5 Aghion, Philippe and Howitt, Peter.(1992) "A Model of Growth Through Creative Destruction." Econometrica, March 1992, 60(2), pp. 323-51.
}

attempt in this models to explain what besides labor and capital, and knowledge accumulation drives innovation. However, Barro (1997) ${ }^{6}$, stated and found that political and economic institutions are some of the most important factors in explaining differences in growth per capita. Unlike neoclassical economist, institutional economist tend to focus on institutions more. The influence of a institutions on the ability of one country to advance technologies is a central way that institutions affect economic performance. However, institutional economist have much more to do in order to include technology and technological change explicitly in their change, Nelson, Nelson $(2002)^{7}$.According to this two authors , Nelson et Nelson (2002), institutions are so called "social technologies", this is in line with Thorsten Veblen's view of institutions as "general habits of action and thought". Now, from our pint of vie we show in the Table 1, with what percentage does technological diffusing products enter in the import of Latin American countries.

\footnotetext{
${ }^{6}$ Barro, Robert,(1997), Determinants of economic growth: A cross-country empirical study. Cambridge, MA: MIT Press, 1997.

${ }^{7}$ Nelson,R.,Nelson,K.,(2002), Technology, institutions, and innovation systems, Research Policy 31 (2002) 265-272
} 
Table 1 Imports of technical progress-diffusing products as a percentage of industrial imports in Latin American countries

\begin{tabular}{l|rrrrrrrrrr}
\hline & $\mathbf{1 9 6 5}$ & $\mathbf{1 9 7 0}$ & $\mathbf{1 9 8 0}$ & $\mathbf{1 9 9 0}$ & $\mathbf{1 9 9 2}$ & $\mathbf{1 9 9 3}$ & $\mathbf{1 9 9 4}$ & $\mathbf{1 9 9 5}$ & $\mathbf{1 9 9 6}$ & $\mathbf{1 9 9 7}$ \\
\hline Mercosur $^{\text {a }}$ and & 30.1 & 39.5 & 37.3 & 41.7 & 37.3 & 36.1 & 38.0 & 35.9 & 38.8 & 41.2 \\
Chile & & & & & & & & & & \\
$\quad$ Argentina & 24.0 & 34.9 & 38.0 & 35.1 & 35.3 & 38.0 & 39.8 & 38.8 & 38.2 & 39.1 \\
$\quad$ Brazil & 34.7 & 43.0 & 40.5 & 45.1 & 43.3 & 36.4 & 39.0 & 36.3 & 41.7 & 44.4 \\
Chile & 36.6 & 40.8 & 27.9 & 42.7 & 33.6 & 36.6 & 37.2 & 34.4 & 34.8 & 36.1 \\
$\quad$ Paraguay & 31.2 & 32.3 & 30.1 & 24.6 & 25.8 & 26.4 & 26.9 & 24.0 & 26.6 & \\
$\quad$ Uruguay & 24.1 & 29.7 & 29.0 & 29.7 & 24.2 & 24.8 & 24.4 & 27.2 & 29.0 & 29.7 \\
& & & & & & & & & & \\
& & & & & & & & & & \\
Andean Community & 36.6 & 38.3 & 35.0 & 38.4 & 35.6 & 36.3 & 34.4 & 34.0 & 36.5 & 37.5 \\
Bolivia & 28.0 & 31.2 & 34.2 & 33.2 & 35.3 & 38.2 & 28.4 & 35.4 & 40.5 & 35.5 \\
Colombia & 44.8 & 40.0 & 32.3 & 37.5 & 34.2 & 34.6 & 36.8 & 37.4 & 38.6 & 39.0 \\
Ecuador & 32.2 & 33.3 & 39.3 & 37.3 & 34.0 & 37.4 & 27.7 & 30.1 & 31.5 & 32.7 \\
Peru & 34.0 & 35.3 & 36.9 & 34.4 & 27.8 & 32.1 & 30.7 & 32.7 & 35.9 & 37.9 \\
Venezuela & 36.6 & 40.1 & 34.9 & 41.6 & 38.9 & 38.9 & 37.4 & 31.9 & 35.2 & $\ldots$ \\
& & & & & & & & & & \\
Mexico & 43.7 & 46.0 & 39.0 & 36.2 & 38.9 & 39.1 & 42.8 & 44.3 & 44.5 & 43.7 \\
& & & & & & & & & & \\
CACM & 26.2 & 26.1 & 24.9 & 25.5 & 26.4 & 27.2 & 25.7 & 25.1 & 24.8 & 25.4 \\
Costa Rica & 26.2 & 26.1 & 26.1 & 26.7 & 25.7 & 28.2 & 25.6 & 26.2 & 25.6 & $\ldots$ \\
El Salvador & 27.9 & 23.8 & 23.1 & 22.6 & 26.2 & 27.9 & 26.8 & 25.0 & 25.6 & 26.1 \\
Guatemala & 25.8 & 25.3 & 21.8 & 26.7 & 271 & 26.5 & 23.0 & 22.1 & 24.2 & 25.8 \\
Honduras & 21.3 & 26.1 & 31.6 & 24.2 & 24.5 & 23.4 & 26.0 & 26.9 & 20.9 & 22.4 \\
Nicaragua & 28.9 & 29.5 & 22.0 & 24.5 & 29.0 & 30.8 & 31.6 & 28.5 & 29.6 & 28.1 \\
& & & & & & & & & & \\
Total & 34.8 & 39.1 & 36.2 & 37.8 & 37.1 & 36.9 & 38.7 & 37.7 & 39.9 & 41.2 \\
\hline
\end{tabular}

Source : ECLAC, on the basis of official

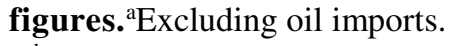

${ }^{\mathrm{b}}$ Mercosur $=$ Southern Common Market.

${ }^{\mathrm{c}} \mathrm{CACM}=$ Central American Market.

As it can be seen from the Table Latin American countries are big importers of technical progress diffusing products, and that throughout time that trend is positive and the import of technology increase. Countries in the table are members of custom union Mercosur and supranational union CACM. Next, for institutions here as proxy variable we take ODA, or Official development assistance.Official development assistance are resource flows provided by bilateral sources and multilateral institutions with the objective of promoting the economic development and welfare of the recipient country. 
Behind this altruistic intention, however, ODA has been used as an instrument of foreign policy of more developed countries to advance their political and commercial interests. Degree of dependency on aid: Where countries are heavily dependent on aid (measured as a proportion of government revenues, on a per capita basis or as a percent of GNI), governments remain vulnerable to sharp fluctuations in aid flows. In some cases, countries may not be especially dependent on aid, but certain sectors within a country may rely heavily on aid to function and thus are vulnerable (e.g., the health sector).About ODA and technical assistance, For instance, technical assistance (which represented 12.7 percent of ODA in 2009) typically involves a contract between a donor agency and a consultant in its own country. The aid recipient receives a service (the consultancy report, training, etc.), but the valuation of the service is beyond its control and no cash transaction takes place with the developing country. On the other hand, volatility associated with this form of aid may be less problematic than that by which funds are channeled directly to recipient countries' budgets,
UNDP, $(2011)^{8}$.So here we set hypothesis that institutions, affect growth of innovations positively in the case of Latin American countries. This variable together with the quantitative measure of human capital, which here we take youth literacy rate (between youth from 15-24 years), as proxy variable for human capital. Next, follows theoretical explanation and mathematical derivation of the econometric equation that we estimate.

\footnotetext{
${ }^{8}$ UNDP,(2011), Towards human resilience: sustaining MDG progress in an age of economic uncertainty, CSE web net
} 


\section{From theoretical to econometric model: Institutional changes in the function of innovation}

The model is developed from Tebaldi and Elmsli $(2008)^{9}$, suggests that technology is related with organization and the quality of institutions.

$$
\dot{A}=\delta A H_{A} Z(I(A))
$$

Where A measures the technical knowledge ,$H_{A}$ measured human capital engaged in research and development, $Z$ marks the quality of institutions ( institutional structure ), which depends from $I$ the sets of institutions, and from technology ( leading technology ). Previous equation we can write the following expression:

$$
A^{\prime}(A)=\delta A H_{A} Z I A
$$

The solution of the previous expression if $A \delta H_{A} I \neq 0$, is given by the following expression:

The result from the previous differential equation can be simplified :

${ }^{9}$ Tebaldi,E.,Elmslie,B.,(2008), Do institutions impact innovation?, Working paper

$$
Z=\frac{1}{A^{2} \delta H_{A} I}
$$

This last expression has 16 solutions, where all values and variables may vary $\pm \mathbf{1}$. If institutional arrangements to improve, the quality of institutions will increase $\frac{\partial Z}{\partial I}>0$, also the assumption that improvements in technology make existing institutions relatively old. Which means, that $\frac{\partial Z}{\partial A}=\frac{\partial Z}{\partial I} \frac{\partial I}{\partial A}<0$, to apply the previous expression for defining the quality of institutions, $Z=\left(\frac{I}{A}\right)^{a}$,or by reexpression $\quad Z=I^{a} A^{-a}$, where $\mathrm{O}<a<1$.

An alternative form of expression

$$
Z=\left(\frac{I}{A}\right)^{a} \text { is }
$$

$Z=I^{a} A^{-a} e^{2 i \pi a\left\lfloor\frac{\arg (A)}{2 \pi}-\frac{\arg (I)}{2 \pi}+\frac{1}{2}\right\rfloor}$. 
If you integrate the indefinite integral we get:

$$
\begin{aligned}
& \int \frac{e^{2 i \pi a\left\lfloor\left[\frac{\arg (A)}{2 \pi}-\frac{\arg (I)}{2 \pi}+\frac{1}{2}\right\rfloor I^{a}\right.}}{A^{a}} d a= \\
& \frac{A^{-a} I^{a} e^{2 i \pi a}\left\lfloor\frac{\arg (A)-\arg (I)+\pi}{2 \pi}\right\rfloor I^{a}}{2 i \pi\left\lfloor\frac{\arg (A)-\arg (I)+\pi}{2 \pi}\right\rfloor-\log (A)-\log (I)}+C
\end{aligned}
$$

According to the expression $Z=I^{a} A^{-a}$, the production function to produce new technologies represent the following expression:

$$
\dot{A}=\delta A^{1-a} H_{A} I^{a}
$$

This variable $\ln \left(I_{i}\right)$ for institutional is a proxy variable because is not exists one single measure known for institutions. By Sala- I- Martin $(2002)^{10}$, institutions affect on the economic performance in the same

\footnotetext{
${ }^{10}$ Sala-i-Martin,X.,(2002), 15 years of new growth economics: what have we learnt?, Central Bank of Chile Working Papers
}

The latter expression is contained the claim that institutions are necessary inputs for production innovations. Good institutions improve the diffusion of knowledge between researchers, assist the implementation of property rights, and assist in the registration of patents, which means that good institutions are expected to positively affect the technical innovations.

Equation $\dot{A}=\delta A^{1-a} H_{A} I^{a}$ is nonlinear differential equation of the first order and can to estimate but can be transformed as discrete differential equation:

$$
\begin{aligned}
& \Delta A_{t}=A_{t}-A_{t-1}= \\
& \delta A_{t-1}^{1-a} H_{A t-1} I^{a}
\end{aligned}
$$

In order, previous econometric equation to estimate can logarithm from both sides:

$$
\begin{aligned}
& \ln \left(\Delta A_{i t}\right)=\beta_{0}+\beta_{1} \ln \left(H_{A i, t-1}\right) \\
& +\beta_{2} \ln \left(A_{i, t-1}\right)+\beta_{3} \ln \left(I_{i}\right)+u_{i, t}
\end{aligned}
$$

way that technology affects the output, which means that the economy has been bad institutions is not effective because more inputs are required to produce the same amount of output. The bad institutions also reduce the incentive to invest in physical capital, human capital and technology. 
Addition, the institutions provide some guiding their behavior, and reduce intrinsic risk which in itself carry innovation. Koenen , Lopez (2009 $)^{11}$. Institutions are important factors that shape innovation processes and provide an explanation for the unequal distribution of innovation between countries and regions. Those institutions that shape innovation often the regulatory domain and in them include: codes of best practices, standards, products, and technologies. By Marx's view, the institutional structure of society is fundamentally conditioned by technology. Marks ( 1859 ) ${ }^{12}$ in his preface to the Contribution to the Critique of Political Economy , writes that a stage of development of the productive forces in society collide with property relations, and continue to be born after that social conflict, new relations of production, but not mature before the foundation of the existing society production relations. The new production relations mean new ways of producing, or a change in technology that will also change the relative performance of the institutional setting (plural of institutions) in the

\footnotetext{
${ }^{11}$ Coenen, L.,Lopez,F.,(2009),Comparing systems approaches to innovation and technological change for sustainable and competitive economies: an explorative study into conceptual commonalities, differences and complementarities, Lund university ${ }^{12}$ Marx,K.,(1859),A Contribution to the Critique of Political Economy, On-Line Version: Marx.org 1993 (Preface, 1993), Marxists.org 1999
}

stability for firms with economy. The effect of institutional changes and related technological change can be analyzed in terms of their effects on transaction costs and on production. The change in technology can also affect transaction costs and may make it more operational institutional placement if previously inoperative, Lin (1989). ${ }^{13}$ Transaction costs for managing the state are reduced if constituents have strict beliefs about the legitimacy of the ruler and the institutions placed on the principle of fairness. The establishment of private property requires the owner has the benefit drawn from these rights to be greater than the cost of excluding others from this property. When the cost of the property is high the ownership will be joint. According to Nelson (2002), the idea of innovation systems is an institutional concept par excellence .The idea that institutions have a central role in innovations system is leading in theorists of the idea for National innovation system (NIS). Such as Edquist and Johnson $(1997)^{14}$, are defining that

\footnotetext{
${ }^{13}$ Lin, Yufi,J.(1989), An economic theory of institutional change: Induced and Imposed change, Cato Journal Vol.9,No.1

${ }^{14}$ Edquist, C. and Johnson, B. (1997). 'Institutions and organisations in systems of innovation', in C. Edquist (ed.) Systems of Innovation: Technologies,
} 
institutions are a set of habits, established practices that govern the relations and interactions between individuals and groups. As an example of the above mentioned are taken patent law of each state and norms affecting relations at universities and enterprises. In the literature on systems of innovation institutions are also known as "social technologies". Alone division of labor is called "physical technology", while the division of labor along the way the coordination is called "social technology", Nelson, Nelson (2002). ${ }^{15}$ The social technologies still seen as generally accepted ways of managing, Williamson (1985). ${ }^{16}$ Usually, in literature for transaction costs, social technology provide a way for something to do with low transaction costs. The objective of innovation system in which central place have institutions is diffusion, adaption and use of innovations, Johnson (2001). ${ }^{17}$ This however, is more theoretical (analytical) objective, in practice agents in

Institutions and Organizations.London and Washington: Pinter/Cassell Academic

${ }^{15}$ Nelson,K,Nelson,R.,(2002),

Technology,

institutions, and innovation systems, Research Policy 31 (2002)

${ }^{16}$ Wiliamson, O.,(1985), TheEconomic institutions of capitalism Firms, Markets, Relational Contracting, Yale University

${ }^{17}$ Johnson,A.,(2001), Functions in Innovation System Approaches, Department of Industrial Dynamics

Chalmers University of Technology SE-412 96

Göteborg innovation system increasingly driven by their objectives that not correspond with social objectives, par example such with the social wealth. Concept of institutions as that are defined as standard social technologies, is consistent with the concept of innovation systems. Institutions despite promote models of stable behavior of economic agents, reduce uncertainty, and encourage markets to provide information, and thus help create more efficient mechanisms of selection, the company level but also at the level of market. Successful examples in economic history describes institutional innovation in terms of reducing transaction costs, and how these innovations allow greater gains from trade also allow expansion markets, North(1990). Now, as an example of institutional change to take the democratization of a country. ${ }^{18}$ Acemoglu (2013). Firstly, we assume that there is an undemocratic government, means power in the hands of the elite, but there are some people that can cause revolution. Which means that there is no limit for revolution.In

18 Different countries have different models of political development, for example many European countries were democratized in $19^{\text {th }}$ century, while many Latin American countries became democratic but they did not succeed to consolidate democracy in the course of $20^{\text {th }}$ century, South Africa for example until the very end of Apartheid faced persistent nondemocracy and repression, same goes for Singapore which face non-democracy with limited repression, Acemoglu (2013), Authorized lectures. 
the model there are two groups of citizens, Elite earns income $y^{1}$, while poor earn income $y^{2}$, and thus $y^{1}>y^{2}$. Simplify the model assuming a standard population to be normalized to 1 . The section of the population $1-s>\frac{1}{2}$ is poor which means most people are poor, the rest is elite. Middle income in the country is denoted with $\bar{y}$, and here we assume that the share of income that accumulated by the rich is $\kappa$

$$
y^{2}=\frac{(1-\kappa) \bar{y}}{1-s} \text { and } y^{1}=\frac{k \bar{y}}{s}
$$

while also assume that $\frac{(1-\kappa) \bar{y}}{1-s}<\frac{k \bar{y}}{s}$, or that $s<k$, while we know that $y^{1}>\bar{y}>y^{2}$.economy in this simplification only fiscal instruments are linear flat tax $\tau \geq 0$ and transfer tax $T$. Costs of taxation are a function of the tax rate $\tau$, respectively $C(\tau) \bar{y}$. Here in the former case, the function $\mathrm{C}$ is increasing and convex. Because taxes are the only government revenue, the budget constraint is given as:

Or the previous expression means that the total utility of agents is equal to the sum of the discounted value of the tax after tax, meaning that the remaining portion of elite and poor people.

$$
T=(\tau-C(\tau)) \bar{y}
$$

What does that $T=\bar{y}-C(\tau) \bar{y}$. Tax rate they prefer poor is given as:

$$
\frac{k-s}{1-s}=C^{\prime}\left(\tau^{2}\right)
$$

While the elite can avoid taxation and its normal point of being it is $\tau^{1}=0$.

Individual utility is defined as the discounted value of income after taxation.

$$
U_{0}^{i}=E_{0} \sum_{t=0}^{\infty} \beta^{t}(1-\tau) \bar{y}_{t}^{i}
$$

In the previous expression $\beta^{t}$ represents the discount factor, while $(1-\tau) \bar{y}_{t}^{i}$ it is a tax after tax. In undemocratic environment policy govern agents who belong to the elite. The only impact on the poor is through de facto power revolution that is undeniable. If the revolution didn't happen

$$
U_{0}^{i}=E_{0} \sum_{t=0}^{\infty} \beta^{t}(1-\tau) y^{i}+\left(\tau_{t}-C\left(\tau_{t}\right) \bar{y}\right)
$$

consumption with total revenues of taxes then remain to fund government spending. If there is a revolution it will succeed but part of the productive capacity of the economy, 
which help to produce new innovative products are forever destroyed. People after the revolution has taken all produced production so far, and the part $\mu$ which every citizen gets to him after the revolution is given by the following expression:

$$
\frac{\left(1-\mu^{r}\right) \bar{y}}{(1-s)}
$$

The total revenue in the economy is given by the expression $(1-\mu) \bar{y}$, and it is divided on $(1-s)$ agents, $\mu^{r}$ is part of $\mu$, but after the revolution. Changes in the part who are received for they the economic agents $\mu$ is a result of changes in the environment, but the elite that controls the government in the undemocratic environment, they can always modify policy and not to respect the promise of redistribution of revenue who they gave it to the people. Members of the elite determine the tax rate $\tau_{t}^{n}$, this tax rate is applied to all people of the economy. Citizens decide whether to start a revolution or not, the revolution record with $\rho_{t}$ and $\rho_{t}=0$, if there is not revolution, $\rho_{t}=1$. If there is revolution the people will obtain the share of output $(1-\mu)$, in the future periods. Institutional disequilibrium can affect different individuals different. The political institutions seem to be reformed and replaced more frequent than traditionally assumed in many political studies, Colomer (2001). ${ }^{19}$ The first ,change of the regime and democratization is a very common of the late 19 th century onward, the second, large change is in the own democratic systems, which they include many changes in alternative systems at elections, third minor institutional reforms are very frequent, sometimes they are small changes which seem to regularly occurs, but sometimes they are large changes that affect the electoral strategies, party system, and the performance of the government. By the Lin(1989), success of the political entrepreneur depends on his ability to separate the potential profits and to convince the members of society that the separate of output is in conformity ( in accordance with their principles ), with their ideologies .Political entrepreneur will exert effort for establishing new rules, if he believes that the benefit from them for him it will larger than real costs. Revenue for political entrepreneur does not have to be material, they can be social prestige and political support. In the literature of evolutionary

\footnotetext{
${ }^{19}$ Colomer,J.,(2001), Introduction disequilibrium institutions and pluralist democracy, Journal of Theoretical Politics, special issue on 'The Strategy of Institutional Change, 13. 3, 2001
} 
economy, the authors in this area recognize the role of institutions and institutional structures in design and support the advanced technology, Nelson and Nelson (2002). And evolutionary economists are observe the institutions then self technological change. But institutions are not yet incorporated into the formal analysis of evolutionary economists. In contrast to, the institutional economists are focus only the institutions. Economists who use the " systems approach " in the economy, use the term technological system, and defined as socially defined and system who design a society, which consists of physical , organizational, scientific and legislative elements, Bath (2011)..$^{20}$

${ }^{20}$ Bhat,B.,(2011),Institutional Change and Technology Adoption in the Electricity Distribution Networks of Andhra Pradesh, (India), Competition and regulation in network industries 


\section{METHODOLOGY AND DATA}

In this study we use Dynamic panel data estimation techniques and linear models, namely GMM type dynamic models, same as fixed and random effect panel regression, also we use GLS panel data model. In this paper we use panel data related to the countries in the sample. Because there is bound to heterogeneity in data for different countries, panel data estimation seems appropriate since it takes into account that heterogeneity, Gujaraty $(2003)^{21}$. Panel data are also more informative data, they include more variability, less collinearity and more efficiency. Estimation of Random effects model by Generalized least squares is easy and routinely done by many econometric software packages. The basic model is as follows:

$y_{i t}=\beta_{0}+\beta_{1} x_{i t 1}+\ldots .+\beta_{k} x_{i t k}+a_{i}+u_{i t}$

Previous equation becomes RE model when unobserved effect $a_{i}$ is uncorrelated with all of the explanatory variables i.e. covariance is zero:

${ }^{21}$ Gujarati, Damodar N. (2003), Basic Econometrics. New York: McGraw-Hill
$\operatorname{Cov}\left(x_{i t n}, a_{i}\right)=0$

$t=1,2, \ldots . T, n=1,2 \ldots k$

Now for the fixed effect if we have the following expression

$y_{i t}=a_{i}+\beta_{1} X_{i t}+u_{i t}, t=1,2 \ldots T$, for each cross-

sectional unit average, this equation becomes,

$\bar{y}_{i t}=a_{i}+\beta_{1} \bar{X}_{i t}+\bar{u}_{i t}$, here $\bar{y}_{i t}=\frac{\sum_{t=1}^{T} y_{i t}}{T}$, if

we subtract two previous equations(in order to eliminate the unobserved time constant $)^{22}$ we get:

$$
\begin{aligned}
& y_{i t}-\bar{y}_{i t}=\beta_{1}\left(x_{i t}-\bar{x}_{i}\right)+u_{i t}-\bar{u}_{i} \\
& =\Delta y_{i t}=\beta_{1} \Delta x_{i t}+\Delta u_{i t}
\end{aligned}
$$

So the fixed effects estimator is efficient when idiosyncratic errors are serially uncorrelated, and there is no assumption about the correlation between the unobserved effect $a_{i}$ and the explanatory variables. Next, just to test for the robustness of the results we employ, Dynamic

22 Wooldridge, Jeffrey , (2002), Econometric Analysis of Cross Section and Panel Data, MIT press 
panel data estimator namely Arelano/Bond GMM estimator ${ }^{23}$, the basic model with lagged dependent variables is :

$$
y_{i t}=a_{i}+y_{i t-1}+u_{i t}, t=1,2 \ldots T
$$

In the previous equation residuals are assumed to follow normal distribution, i.e. $u_{i t}, \sim\left(0, \sigma_{u}^{2}\right)$. Here $y_{i t-1}$ depends positively on $a_{i}$, this is easy to see when we are inspecting the model for $\mathrm{t}-1$ period ;

$$
\gamma y_{i t-1}=a_{i}+\gamma y_{i t-2}+u_{i t-1}, t=1,2 \ldots T
$$

So there exist endogeneity problem and OLS and GLS, i.e. FE and RE are not consistent. But the Arelano/Bond GMM estimator is consistent. The moment conditions use the properties of the instruments, and the instruments in the GMM Arelano /Bond model are the differenced explanatory variables:

23Arellano, Manuel \& Bond, Stephen, (1991), Some Tests of Specification for Panel Data: Monte Carlo Evidence and an Application to Employment Equations, Review of Economic Studies, Wiley Blackwell, vol. 58(2), pages 277-97, April. $y_{i t-m} ; m \geq 2$

So that the instruments are uncorrelated with the future errors $u_{i t}$ and $u_{i t-1}$. So the increasing number of moment of conditions is $t=3,4 \ldots T$. GMM estimation is combined with RE and FE estimator because as $T \rightarrow \infty$, estimates of the RE and FE model begin to converge.

The data that were used in this study were collected from the World bank data site ${ }^{24}$. Variables that are used for the estimation of the model are shown in table 2.

\footnotetext{
${ }^{24}$ http://search.worldbank.org/data?qterm=royalty\& language=EN\&format $=$
} 


\begin{tabular}{|c|c|}
\hline Name of the variable & Variable label \\
\hline $\begin{array}{l}\text { Patents (proxy for technology) } \\
\text { indicator for } \\
\text { Science\&TechnologyInfrastructure }\end{array}$ & $\begin{array}{l}\text { Innovation, intellectual property, inventions, } \\
\text { applications, Patent applications } \\
\text { Technology, invention, Patent application, Patent } \\
\text { applications resident, patent }\end{array}$ \\
\hline $\begin{array}{l}\text { Literacy rate, youth total (\% of } \\
\text { people ages 15-24) (proxy for } \\
\text { human capital) }\end{array}$ & $\begin{array}{l}\text { Development goals, Education, Education outcomes, goal } \\
\text { 2, Illiteracy, international goals, Literacy, MDGs, } \\
\text { millennium goals, Target 2, young people, youth, Youth } \\
\text { illiteracy, Youth literacy, development goal, dev goal, } \\
\text { Education outcome, international goal, MDG, millennium } \\
\text { goal }\end{array}$ \\
\hline $\begin{array}{l}\text { Aid Effectiveness Economic } \\
\text { Policy \& Debt Official } \\
\text { development assistance ODA } \\
\text { (proxy for institutions) }\end{array}$ & $\begin{array}{l}\text { Net official development assistance (ODA) consists of } \\
\text { disbursements of loans made on concessional terms (net of } \\
\text { repayments of principal) and grants by official agencies of } \\
\text { the members of the Development Assistance Committee } \\
\text { (DAC), by multilateral institutions, and by non-DAC } \\
\text { countries to promote economic development and welfare in } \\
\text { countries and territories in the DAC list of ODA recipients. } \\
\text { It includes loans with a grant element of at least } 25 \text { percent } \\
\text { (calculated at a rate of discount of } 10 \text { percent). Data are in } \\
\text { current U.S. dollars. }\end{array}$ \\
\hline
\end{tabular}

\section{Descriptive statistics of the model}

Next, what follows is the panel descriptive statistics of the three variables that are being used in the model. 
Table 3 Descriptive statistics of the variables

\begin{tabular}{|c|c|c|c|c|c|c|c|}
\hline Variable & $\begin{array}{c}\text { Variable } \\
\text { name }\end{array}$ & & Mean & Std. Dev. & Min & Max & Observation \\
\hline \multirow[t]{3}{*}{$\log \mathrm{A}$} & $\begin{array}{l}\text { Logarithm } \\
\text { of } \\
\text { technology }\end{array}$ & overall & 39.07447 & 22.1278 & 1 & 79 & $\mathrm{~N}=94$ \\
\hline & & between & & 16.83431 & 10.33333 & 60.61111 & $\mathrm{n}=6$ \\
\hline & & within & & 18.1904 & 2.863942 & 80.86394 & $\mathrm{~T}-\mathrm{bar}=15.67$ \\
\hline \multirow[t]{3}{*}{$\log \mathrm{H}$} & $\begin{array}{l}\text { Logarithm } \\
\text { of human } \\
\text { capital }\end{array}$ & overall & 20.68293 & 11.60267 & 1 & 40 & $\mathrm{~N}=41$ \\
\hline & & between & & 10.79168 & 5.333333 & 37.5 & $\mathrm{n}=6$ \\
\hline & & within & & 6.860657 & 0.238482 & 32.34959 & $\mathrm{~T}-\mathrm{bar}=6.83$ \\
\hline \multirow[t]{3}{*}{$\log I$} & $\begin{array}{l}\text { Logarithm } \\
\text { of } \\
\text { institutions }\end{array}$ & overall & 24.83929 & 19.01519 & 1 & 65 & $\mathrm{~N}=112$ \\
\hline & & between & & 18.58029 & 6.105263 & 53.47368 & $\mathrm{n}=6$ \\
\hline & & within & & 8.410199 & -12.6607 & 58.47086 & $\mathrm{~T}-\mathrm{bar}=18.667$ \\
\hline
\end{tabular}

In the econometric part we use following equation:

$$
\begin{aligned}
& \ln \left(\Delta A_{i t}\right)=\beta_{0}+\beta_{1} \ln \left(H_{A i, t-1}\right) \\
& +\beta_{2} \ln \left(A_{i, t-1}\right)+\beta_{3} \ln \left(I_{i}\right)+u_{i, t}
\end{aligned}
$$

variable lagged once, while $\ln \left(I_{i}\right)$ is the logarithm of the institutions (quality of institutions) variable. Given the title of this investigation, hence the following graph that shows the movement of the technological growth and the quality of institutions through the panel of countries.

In the previous equation $\ln \left(\Delta A_{i t}\right)$ is the growth of the technology variable, $\ln \left(H_{A i, t-1}\right)$ is the human capital variable lagged once, $\ln \left(A_{i, t-1}\right)$ is the technology 
Figure 1 Dynamic panel for the movement of the quality of institutions variable together with technological growth (patents growth)

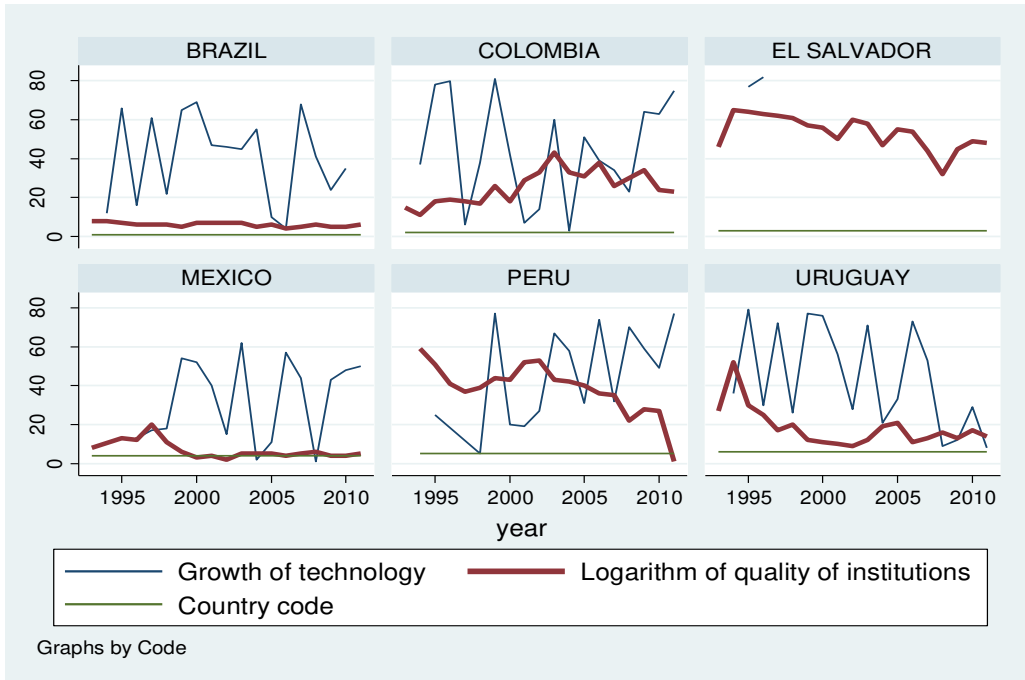

From the Figure 1 we can see that the movement of the two variables (quality of institutions and technological growth) is not stationary. But the first difference of the variables is stationary. This statement we prove with Fisher panel unit root test. For paneldata, panel unit root tests have been proposed by Levin and Lin (1992), Im, Pesaran andShin (1997), Harris and Tzavalis (1999), Madala and Wu (1999), Choi (1999), Hadri (1999),and Levin, Lin and Chu $(2002)^{25}$. 
Table 4. Fisher Test for panel unit root using an augmented Dickey-Fuller test (0 lags)

\begin{tabular}{lccc}
\hline \hline Ho: unit root & D.logA & D. $\log \mathbf{H}$ & D. $\log \mathbf{I}$ \\
\hline \hline$\chi^{2}(10) ; \chi^{2}(12)$ & 99.7920 & 52.0591 & 159.3815 \\
$; \chi^{2}(12)$ & & & \\
$\mathrm{P}>\chi^{2}$ & 0.0000 & 0.0000 & 0.0000 \\
\hline \hline
\end{tabular}

From the above results from the test all of the variables are $\mathrm{I}(1)$, or it means they are stationary when first differenced.

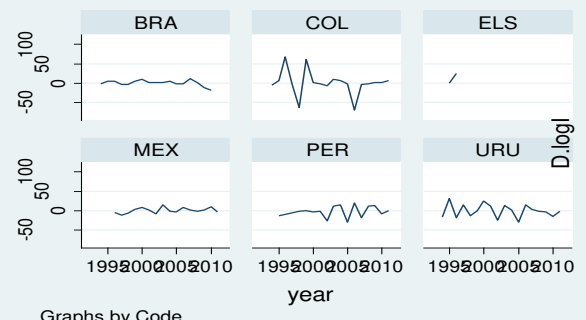

Graphs by Code

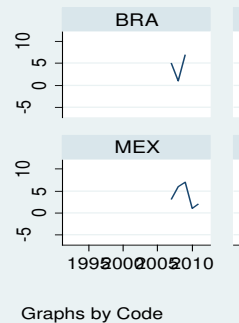

$\mathrm{COL}$

\section{N}

PER
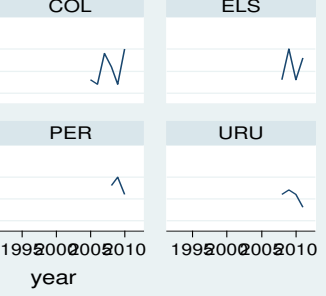

Figure 2 Combined table of graphs of first difference of the variables of interest (technology, institutions, and human capital)
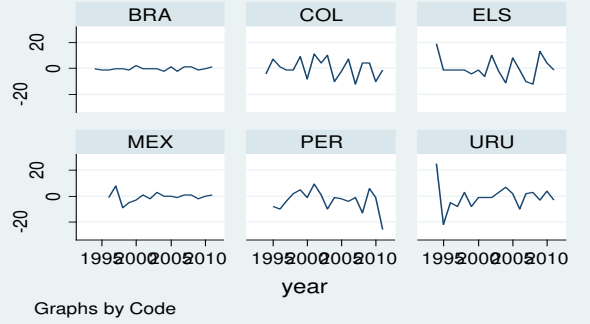

Graphs by Code
From the above table can be seen that the three series in the six panels are stationary, i.e. they move around mean zero and they all have some variance. 


\section{Econometric estimation and results}

In this paper panel data set was used with 112 observation for six panels. Namely, in our panel of countries enter: Brazil, Columbia, El Salvador, Mexico, Peru, and
Uruguay. This sample is consisted of the data for the mentioned Latin American countries. Results are presented in the following tables.

\section{Table 5 Dynamic panel data estimation GMM model}

\begin{tabular}{|c|c|c|c|}
\hline \multicolumn{4}{|c|}{ Dynamic panel-data estimation } \\
\hline \multicolumn{4}{|c|}{ Group variable: Code, Time variable :year } \\
\hline \multicolumn{2}{|c|}{$\begin{array}{l}\text { GrowthA } \\
\text { Dependent variable technological } \\
\text { growth }\end{array}$} & Coefficient & $P>|z|$ \\
\hline llogh & $\begin{array}{c}\text { First lag of } \\
\text { logarithm human } \\
\text { capital } \ln \left(H_{A i, t-1}\right)\end{array}$ & $9.10 \mathrm{E}-06$ & 0.058 \\
\hline$L \log A$ & $\begin{array}{c}\text { First lag of } \\
\text { logarithm of } \\
\text { technology } \ln \left(A_{i, t-1}\right)\end{array}$ & 0.060384 & 0.498 \\
\hline $\log I$ & $\begin{array}{c}\text { Logarithm of } \\
\text { institutions quality } \\
\text { measure } \ln \left(I_{i}\right)\end{array}$ & -0.73376 & 0.018 \\
\hline Constant & Intercept & 53.8001 & 0.000 \\
\hline \multicolumn{2}{|c|}{$\begin{array}{l}\text { Wald test } \chi^{2}(3) H_{0}: \text { the joint null } \\
\text { hypothesis is that the instruments are } \\
\text { valid instruments }\end{array}$} & 9.85 & 0.0199 \\
\hline \multicolumn{2}{|c|}{ Number of observations } & \multicolumn{2}{|c|}{86} \\
\hline \multicolumn{2}{|c|}{ Number of groups } & \multicolumn{2}{|c|}{6} \\
\hline \multicolumn{4}{|c|}{$\begin{array}{l}\text { Instruments for differenced equation } \\
\text { GMM-type: } L(2 / .) \cdot \log A \text { L }(2 / .) \cdot \log H L(2 / .) \cdot \log I \\
\text { Instruments for level equation } \\
\text { Standard: Constant }\end{array}$} \\
\hline
\end{tabular}


Dynamic panel data models estimate the effects on some observed outcome of other variables of interest, which may be exogenous or potentially endogenous, conditional on both unobserved individual heterogeneity and one or more lags of the dependent variable. We may illustrate the principle by the simplest possible model that gives empirical form to Equation (1):

$$
y_{t}=\beta x_{t}+\varepsilon_{t}
$$

in which case, rearranging previous Equation

$$
\varepsilon_{t}=\left(y_{t}-\beta x_{t}\right)
$$

and, substituting into ,

In Equation (25), only $\hat{\beta}$ (the estimated value of $\beta$ ) is unknown and so may be derived analytically. Equation (25) is also the first-order condition for the minimisation of the least-squares criterion for deriving the OLS estimate of $\beta$. In this case, the GMM and OLS estimators are equivalent, because OLS is a particular estimation method within the broader class of GMM methods. However, OLS uses only as many moments as there are parameters to be estimated. In contrast, GMM estimation may use more moments than there are parameters to be

$$
\mathrm{E}\left(\varepsilon_{t}, x_{t}\right)=\mathrm{E}\left[\left(y_{t}-\beta x_{t}\right), x_{t}\right]=0
$$

For estimation, the empirical moment equation is the sample counterpart to the middle term in Equation :

$$
\frac{1}{N} \sum_{i=1}^{T}\left(y_{t}-\hat{\beta} x_{t}\right) x_{t}=0
$$

estimated $^{26}$. From the Table 4 we can observe that lagged Human capital variable is positively and statistically significantly associated with the growth of technology, pvalue is 0.058 , but the coefficient itself is of very small size. While the coefficient on quality of institutions measured by the Official development assistance is negative and statistically significant, p-value is 0.018 ,

\footnotetext{
${ }^{26}$ StataCorp (2007) STATA Logitudinal/Panel Data Reference Manual: Release 10. College Station, Texas StataPress.
} 
and the coefficient is of size - 0.73 .This is perhaps not in line with the conventional wisdom, but the appriori knowledge that institutions influence positively on patents and protection of property rights works only for "good" institutions.But bad institutions as supposedly from this result the sample of Latin American countries have, influence bad on technology. Second, as it was said in the introduction Latin American countries are importers of technical progress diffusing products, as it can be seen from the Table 1 that their imports up to $40 \%$ is consisted of technical progress diffusing products, that is also that they do not produce this but they are buying technology, also with the loans and grants from the multinational institutions (ODA proxy for quality of institutions), they are paying their imports of high tech products. While, the coefficient on the lagged technology is positive but insignificant when regressed with the technological growth. Next, for a robustness check we run Random effects Generalized least squares regression.

Table 6 RE GLS regression with AR(1) disturbances

\begin{tabular}{|c|c|c|c|}
\hline \multicolumn{4}{|c|}{ "RE GLS regression with AR(1) disturbances } \\
\hline \multicolumn{4}{|c|}{ Group variable: Code, Time variable :year } \\
\hline \multicolumn{2}{|c|}{$\begin{array}{l}\text { GrowthA } \\
\text { Dependent variable technological growth } \\
\end{array}$} & Coefficient & $P>|z|$ \\
\hline llogh & $\begin{array}{l}\text { First lag of logarithm } \\
\text { human capital } \\
\ln \left(H_{A i, t-1}\right)\end{array}$ & 7.91E-06 & 0.0106 \\
\hline $\operatorname{Llog} A$ & $\begin{array}{l}\text { First lag of logarithm of } \\
\text { technology } \ln \left(A_{i, t-1}\right)\end{array}$ & 0.070472 & 0.441 \\
\hline $\log I$ & $\begin{array}{l}\text { Logarithm of institutions } \\
\text { quality measure } \ln \left(I_{i}\right)\end{array}$ & 0.210005 & 0.0236 \\
\hline Constant & Intercept & 34.8058 & 0.000 \\
\hline \multicolumn{2}{|c|}{$\begin{array}{l}\text { Wald test } \chi^{2}(3) H_{0} \text { :the joint null hypothesis is } \\
\text { that the instruments are valid instruments }\end{array}$} & 3.75 & 0.4410 \\
\hline \multicolumn{2}{|c|}{ Estimated correlation coefficient } & \multicolumn{2}{|c|}{-0.03447467} \\
\hline \multicolumn{2}{|l|}{ R-squared } & \multicolumn{2}{|c|}{0.9349} \\
\hline \multicolumn{2}{|c|}{ Number of observations } & \multicolumn{2}{|c|}{86} \\
\hline \multicolumn{2}{|c|}{ Number of groups } & \multicolumn{2}{|c|}{6} \\
\hline
\end{tabular}


Generalized least squares (GLS) is a technique for estimating the unknown parameters in a linear regression model. The GLS is applied when the variances of the observations are unequal (heteroscedasticity), or when there is a certain degree of correlation between the observations. From the table it can be seen that the estimated correlation coefficient is low -0.034 . Coefficient of determination is high 0.9349.Next, we do RE GLS regression but with a comparison by years. The coefficient on the institutions is positive 0.0097 and statistically significant 0.0545

\section{Random-effects GLS regression}

\begin{tabular}{|c|c|c|c|c|}
\hline \multirow{2}{*}{$\begin{array}{l}\begin{array}{c}\text { Dependent variable: } \\
\text { Technological } \\
\text { growth }\end{array} \\
\text { Independent } \\
\text { variable :Logarithm } \\
\text { of institutions } \\
\text { quality }\end{array}$} & \multirow{2}{*}{$\begin{array}{c}\text { Coefficient } \\
0.097497\end{array}$} & \multirow{2}{*}{$\begin{array}{c}\mathbf{P}>|\mathbf{z}| \\
0.0545\end{array}$} & \multicolumn{2}{|c|}{$\begin{array}{l}\text { [95\% Conf. } \\
\text { Interval] }\end{array}$} \\
\hline & & & -0.21826 & 0.41325 \\
\hline \multicolumn{5}{|l|}{ year } \\
\hline 1995 & 35.6592 & 0.029 & 3.644101 & 67.67429 \\
\hline 1996 & 15.73667 & 0.333 & -16.1145 & 47.58785 \\
\hline 1997 & 11.48727 & 0.5 & -21.9264 & 44.90098 \\
\hline 1998 & -6.03935 & 0.71 & -37.9279 & 25.84921 \\
\hline 1999 & 42.96065 & 0.008 & 11.0721 & 74.84921 \\
\hline 2000 & 24.17515 & 0.138 & -7.7558 & 56.10609 \\
\hline 2001 & 5.785157 & 0.722 & -26.0799 & 37.65026 \\
\hline 2002 & -2.05384 & 0.899 & -33.9151 & 29.80742 \\
\hline 2003 & 32.82916 & 0.043 & 0.976414 & 64.68191 \\
\hline 2004 & -0.25384 & 0.988 & -32.1151 & 31.60742 \\
\hline 2005 & -0.83434 & 0.959 & -32.6975 & 31.02877 \\
\hline 2006 & 21.56065 & 0.185 & -10.3279 & 53.44921 \\
\hline 2007 & 18.53615 & 0.255 & -13.386 & 50.45826 \\
\hline 2008 & 1.214145 & 0.941 & -30.7261 & 33.15441 \\
\hline 2009 & 12.73615 & 0.434 & -19.186 & 44.65826 \\
\hline 2010 & 17.27264 & 0.289 & -14.6825 & 49.22783 \\
\hline 2011 & 25.42601 & 0.138 & -8.13062 & 58.98263 \\
\hline Constant & 26.0259 & 0.052 & -0.23802 & 52.28982 \\
\hline R-squared & \multicolumn{4}{|c|}{0.9658} \\
\hline
\end{tabular}


so from the previous table we can see that the highest marginal contribution of ODA to technological growth we have in 1999 , this is also proven graphically on the following chart.

\section{Figure 3 Marginal contribution of ODA to technological growth}

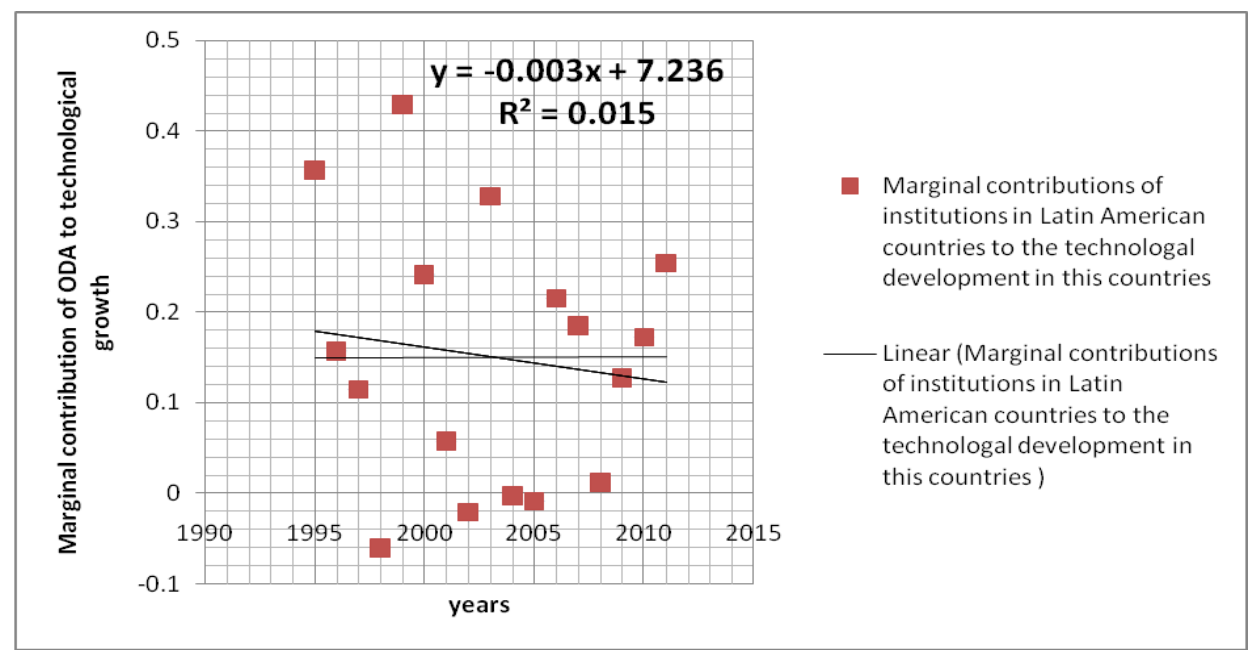

But from the previous figure we can see that the overall marginal coefficient on the quality of institutions is negative, that means that overall contribution to innovations growth is negative. Coefficient of the determination is $15 \%$. So, we have ambiguous relationship between quality of institutions and technological growth based on our results for the sample of Latin American countries.

\section{Conclusion}

So by investigating the link between institutions and innovations growth in Latin American countries, we confirm conventional wisdom about the sign of this relationship, which is supposed to be positive. This relationship is robust, but in the first model (DPD) model, this sign is negative with size -0.73 and $p$-value 0.018 , this is in line with the notion that institutions in this countries are not from such quality like let say North America. The sign on the quality of institutions variable is positive in Random effect panel models. While the sign on human capital variable is positive in all models as expected from apriori knowledge. 


\section{References}

1. Aghion, Philippe and Howitt, Peter.(1992) "A Model of Growth Through Creative Destruction." Econometrica, March 1992, 60(2), pp. 323-51.

2. Arellano, Manuel \& Bond, Stephen, (1991), Some Tests of Specification for Panel Data: Monte Carlo Evidence and an Application to Employment Equations, Review of Economic Studies, Wiley Blackwell, vol. 58(2), pages 277-97, April.

3. Barro, Robert,(1997), Determinants of economic growth: A cross-country empirical study. Cambridge, MA: MIT Press, 1997.

4. Choi, I. (1999), "Unit Root Tests for Panel Data,"manuscript of Kookmin University, Korea.

5. Coenen, L.,Lopez,F.,(2009),Comparing systems approaches to innovation and technological change for sustainable and competitive economies: an explorative study into conceptual commonalities, differences and complementarities,Lund university

6. Edquist, C. and Johnson, B. (1997). 'Institutions and organisations in systems of innovation', in C. Edquist (ed.) Systems of Innovation: Technologies, Institutions and Organizations.London and Washington: Pinter/Cassell Academic

7. Grossman, Gene and Helpman, Elhanan(1991). "Quality Ladders in the Theory of Growth." Re-view of Economic Studies, January 1991, 58(1), pp. 43-61.

8. Huang, Haizhou and Chenggang Xu (1999). "Institutions, Innovations and Growth," American Economic Review, 89(2): 438443.

9. Johnson,A.,(2001), Functions in Innovation System Approaches, Department of Industrial Dynamics Chalmers University of Technology SE-412 96 Göteborg

10. Lin,Yufi,J.(1989), An economic theory of institutional change: Induced and Imposed change, Cato Journal Vol.9, No.1

11. Marx,K.,(1859),A Contribution to the Critique of Political Economy, On-Line Version: Marx.org 1993 (Preface, 1993), Marxists.org 1999
12. Nelson,K,Nelson,R.,(2002), Technology, institutions, and innovation systems, Research Policy 31 (2002)

13. Romer, Paul,(1990) ,Endogenous Technological Change." Journal of Political Economy, October 1990, 98(5), pp. '71-102.

14. Sala-i-Martin,X.,(2002), 15 years of new growth economics: what have we learnt?, Central Bank of Chile Working Papers

15. StataCorp (2007) STATA Logitudinal/Panel Data Reference Manual: Release 10. College Station, Texas StataPress.

16. UNDP,(2011), Towards human resilience: sustaining MDG progress in an age of economic uncertainty, CSE web net

17. Wiliamson, O.,(1985), The Economic institutions of capitalism Firms, Markets, Relational Contracting, Yale University

18. Tebaldi,E.,Elmslie,B.,(2008), Do institutions impact innovation?, Working paper 